Institute for Research on Poverty

Discussion Paper no. 1108-96

\title{
The Impact of School Resources on Women's Earnings and Educational Attainment: Findings from the National Longitudinal Survey of Young Women
}

\author{
Julian R. Betts \\ Department of Economics \\ University of California, San Diego
}

September 1996

This research was supported by a grant from the Bureau of Labor Statistics, U.S. Department of Labor, and the Institute for Research on Poverty at the University of Wisconsin. I thank Ron White for excellent research assistance, and participants at the Spring 1996 IRP conference in Washington, D.C., for helpful comments.

IRP publications (discussion papers, special reports, and the newsletter Focus) are now available electronically. The IRP Web Site can be accessed at the following address:

http://www.ssc.wisc.edu/irp. 


\begin{abstract}
This research measures the impact of high school resources on women's educational attainment and earnings. No link emerges between education and school resources, whether measured by the pupilteacher ratio, spending per pupil, teachers' starting salaries, or books per student. For white women, no significant connection between school resources and wages is found. But school inputs are in several cases significantly and positively related to black women's wages. Wage elasticities with respect to school inputs are uniformly larger for black women. Finally, the impact of school resources on earnings remains constant or in some cases depreciates as workers grow older.
\end{abstract}




\section{The Impact of School Resources on Women's Earnings and Educational Attainment: Findings from the National Longitudinal Survey of Young Women}

\section{INTRODUCTION}

Each year public authorities spend approximately $\$ 200$ billion on educating the nation's children in primary and secondary schools. ${ }^{1}$ Administrators must decide how to allocate resources along a variety of margins. Historically, increases in the school leaving age have raised total educational spending because the proportion of young people enrolled rose in response. More recently, educational expenditures have risen as government has increased real spending per pupil. Hanushek $(1986,1989,1991)$ notes that real spending per pupil more than doubled between the mid-1960s and the mid-1980s. During the same period, the pupil-teacher ratio dropped by approximately one-third, and the percentage of teachers who held postgraduate degrees more than doubled.

Given the scarcity of public funds, it becomes important to measure the overall effectiveness of educational expenditures. It is also important to know if some margins of spending-teacher salaries, spending to reduce class size, or instructional resources such as school books-are more effective than others. In his reviews, Hanushek finds that most studies of test scores have found that additional expenditures do not have a systematic relationship with students' test scores or gains in test scores.

A smaller literature attempts to measure student outcomes based on students' earnings once they enter the labor market. Since one of the main goals of public education is to prepare students for the labor market, this seems like a useful approach.

A recent review of the literature on the impact of school resources on earnings and educational attainment indicated mixed results (see Betts 1996a). Studies that use proxies for the school resources allocated to each student based on his state of birth and state-level averages of school resources

${ }^{1}$ U.S. Bureau of the Census 1992: 280. 
typically find a positive and significant link to both earnings and educational attainment. However, my findings indicate that the internal rate of return to school spending based on these measures is quite low, on the order of 2 to 3 percent. Moreover, recent work by Heckman, Layne-Farrar, and Todd (1995) reports that the estimated impact of school resources on earnings becomes much weaker in the statelevel literature once one allows for nonlinear returns to education. Several studies that measure school resources at the actual school attended generally report no significant link between school resources and earnings, and smaller elasticities than in the state-level literature. (See, for example, Altonji 1988; Betts 1995; Grogger 1996; also see Betts 1996a.)

Surprisingly, each of the twenty-three studies reviewed in Betts 1996a examines the impact of school spending on the earnings of adult men only. This gap in our knowledge greatly restricts our ability to gauge the effectiveness of school spending. If the returns are higher for women, the case for further increasing school spending could be much greater than stated in the literature reviewed.

The goal of this paper is to present the first study that specifically examines the impact of school resources on labor market outcomes of women. ${ }^{2}$ Using data from the National Longitudinal Survey of Young Women (NLS-YW), two measures of adult outcomes are examined. First, the educational attainment of women is modeled as a function of various measures of school inputs and other background variables. Second, the log hourly wage of women is modeled. Since selectivity bias arises in models of women's earnings due to endogenous labor force participation, I use the Heckman two-step correction for selection into employment.

The NLS-YW is a useful data set for modeling the impact of school resources on outcomes for women. A first advantage is that school inputs such as teacher salaries and class size are available for the actual high school or school district attended by each woman, based on a 1968 survey of each of the

\footnotetext{
${ }^{2} \mathrm{~A}$ recent paper by Altonji and Dunn (1995) models the impact of school inputs on earnings using a pooled sample of men and women, but does not present separate estimates for women.
} 
schools. Second, the NLS-YW provides a very long series of observations on labor force outcomes for women. The survey began in 1968 and provides a series of annual surveys up to 1973; thereafter it provides survey data spaced from one to three years apart, for a total of sixteen surveys. I use all the available data up through the 1991 interview. I can thus follow the labor market progress of women from their teens up through their ages in 1991, which ranged from 37 to 50.

The broad range of ages allows for a convincing test of whether the impact of school resources on adult outcomes increases with the worker's age. As has been noted (see Betts 1996a), one way to explain the weak or nonexistent estimated impact of school resources on adult earnings in the earlier studies which measure school inputs at the level of the actual school attended is to appeal to age dependence. With one exception (Wachtel 1975) all of these school-level studies observe the earnings of workers when they are between the ages of 17 and 32. Card and Krueger (1996) suggest that the school-level literature (in particular Betts 1995 and Grogger 1996), does not provide good measures of the life-cycle effect of school spending on wages for precisely this reason. New evidence (Betts forthcoming 1996b) suggests that the effect of school spending on earnings is not age-dependent for white males. ${ }^{3}$ The NLS-YW, with its unusually wide range of ages, combined with detailed data on the schools attended by each woman, provides a unique opportunity to test this hypothesis further.

The next section describes the data set, and section 3 details the results, first for educational attainment, and second for a model of log wages. Section 4 concludes.

${ }^{3}$ I replicate earlier work which models Census earnings data as a function of school resources in the worker's state of birth, and explicitly tests for age dependence. I found that the estimated impact of school spending is just as strong for workers in their twenties as for older workers. I also modeled predicted mid-career earnings of workers in the National Longitudinal Survey of Youth based on the occupation they held in 1989, when they were 32 years old or younger, and failed to find a significant link between these predicted earnings and school resources. 


\section{DATA}

I study outcomes for all black and white women who were interviewed as part of the NLS-YW. Means and standard deviations are provided for both samples, based on the observations used in the education model, in Table A.1. Corresponding information for the sample used for the wage regressions appears in Table A.2. I use four principal measures of the resources devoted to education: spending per pupil in the student's school district, the pupil-teacher ratio in the school, the school district's salaries for inexperienced teachers with a bachelor's degree, and books per student in the school. Both the spending per pupil and teachers' salary variables are adjusted for variations in the cost of living in the given city by the administrators of the NLS. This is important because it reduces the risk that these financial variables will be biased upward in wage models simply because they are acting as proxies for the cost of living in an area (and for the subsequent earnings of women after they leave school and start working in the area). Because the most detailed information provided on the location of the school is the (nine-level) Census region, it is not possible to control for variations in the cost of living nearly as accurately simply by adding region dummies to the regressions.

Section 3.1, which models educational attainment, uses the latest observation available on years of schooling obtained for each woman. Section 3.2, which models log hourly wages, uses all observations for which the woman is 18 or older and does not report attending school or college. (Wages during years in which the woman is enrolled are dropped from the sample to avoid the possibility that the coefficients on the high school resources might be biased downward if women who attend better high schools are more likely to attend college, and at the same time take poorly paying temporary jobs to pay for college.) 


\section{RESULTS}

\subsection{Educational Attainment}

I begin by modeling educational attainment for the final year in which information on educational attainment is available for each woman. Recent evidence by Heckman, Layne-Farrar, and Todd (1995) suggests that the returns to education, and to school spending, are highly nonlinear, exhibiting jumps when people obtain high school or postsecondary degrees. Therefore, I allocate each woman to one of five categories based on years of education (EDUC) and the degrees she has obtained. Below HDEG, the highest degree, is either a high school diploma, bachelor's degree, or postgraduate degree:

$$
\mathrm{ED}=\left\{\begin{array}{l}
1 \text { if EDUC }<12 \\
2 \text { if HDEG }=\text { High School Diploma and EDUC } \leq 12 \\
3 \text { if HDEG }=\text { High School Diploma and EDUC }>12 \\
4 \text { if HDEG }=\text { Bachelor's } \\
5 \text { if HDEG }=\text { Master's or Ph.D. }
\end{array}\right.
$$

Note that all women who hold a high school diploma but not a bachelor's or higher, and who report more than twelve years of education, are coded as ED=3, signifying "some college." ${ }^{4}$ This ED variable can be modeled using an ordered probit.

An important characteristic of the data is that in the final year in which educational attainment was observed, about 7 percent of women were enrolled in formal education, even though the average woman in the sample is in her late thirties at the time that educational attainment is measured (see

${ }^{4}$ An alternative would have been to categorize women with an associate degree as distinct from those with some years of college but no postsecondary degree, but the number of women who reported holding an associate degree as their highest degree was very small relative to the number who were high school graduates with one or more years of college education. Since the goal here was to estimate an ordered probit model, and there is no obvious ordering of these two groups, women with associate degrees were combined with the larger pool of women with high school diplomas and some years of college with no degree. 
Table A.1). A simple ordered probit is likely to produce biased estimates if this problem is ignored. Accordingly, an ordered probit model which controls for right censoring due to enrollment was estimated. The log likelihood function is given by the following expression, where $\mathrm{X}_{\mathrm{i}}$ is the set of explanatory variables for person $\mathrm{i}, \mathrm{ENROLL}_{\mathrm{i}}$ is a dummy variable indicating whether the person was enrolled, $\beta$ is the set of coefficients, and $\alpha_{1}, \alpha_{2}$, and $\alpha_{3}$ are the thresholds in the underlying latent variable model:

$$
\begin{gathered}
\log L= \\
\left(1-E N R O L L_{i}\right)\left(\begin{array}{l}
\sum_{E D_{i}=1} \log F\left(-X_{i} \beta\right)+\sum_{E D_{i}=2} \log \left[F\left(\alpha_{1}-X_{i} \beta\right)-F\left(-X_{i} \beta\right)\right] \\
+\sum_{E D_{i}=3} \log \left[F\left(\alpha_{2}-X_{i} \beta\right)-F\left(\alpha_{1}-X_{i} \beta\right)\right]+\sum_{E D_{i}=4} \log \left[F\left(\alpha_{3}-X_{i} \beta\right)-F\left(\alpha_{2}-X_{i} \beta\right)\right]
\end{array}\right)+\sum_{E D_{i}=5} \log \left[1-F\left(\alpha_{3}=X_{i} \beta\right)\right] \\
+\operatorname{ENROLL}_{i}\left(\begin{array}{l}
\sum_{E D_{i}=1} \log (1)+\sum_{E D_{i}=2} \log \left[1-F\left(-X_{i} \beta\right)\right] \\
+\sum_{E D_{i}=3} \log \left[1-F\left(\alpha_{1}-X_{i} \beta\right)\right]+\sum_{E D_{i}=4} \log \left[1-F\left(\alpha_{2}-X_{i} \beta\right)\right]
\end{array}\right.
\end{gathered}
$$

Note that the contribution to the log likelihood function for those who already have a postgraduate degree does not depend on whether the person is currently enrolled, while a person who is currently enrolled and for whom $\mathrm{ED}=1$ provides no information at all, since her ultimate level of education could range from level 1 through 5.

The regressors comprising the vector $\mathrm{X}_{\mathrm{i}}$ are a constant, age and its square, number of children, dummies indicating whether the woman was married, lived in the South, or lived in a city of 25,000 or more at the time of the education observation, and dummies indicating location of the school for eight of the nine Census regions. Given Taubman's (1989) summary of the importance of family background in determining educational achievement, the model also includes four family background variables which derive from questions asked in 1968, the first year of the survey: father's and mother's years of education, the Duncan socioeconomic index of the job held by the head of the person's household when 
she was 14 years old, and the number of siblings the woman had in 1968. Some observations had missing values for one or more of these four variables. ${ }^{5}$ It clearly would not be appropriate to discard such people, and so the variables were set to 0 in such cases. Four dummy variables were added to the regression to control for observations which were missing one of these background variables.

Tables 1 and 2 show the results of the ordered probits with censoring for white women and black women respectively. In order to increase the precision of the estimates, each of the measures of school resources is entered in separate equations. (The absolute value of the correlation coefficients between the four measures of school resources is typically in the range 0.05 to 0.4. See Table A.3.) For both white and black women, the personal and family background variables are highly significant predictors of educational attainment. Particularly striking is the degree of intergenerational transmission of educational attainment between mother and daughter. The sample of black women is much smaller than that for white women, and so in general the levels of significance are lower in the black sample. Note that the impact of some of the background variables on educational attainment, in particular marital status and the number of children, differs substantially between the two races.

Despite the smaller sample size for black women, there typically appears to be greater evidence of a positive and significant link between school resources and educational attainment among black women than for white women. In the white sample, the coefficients on the pupil-teacher ratio and spending per pupil have perverse signs. The only school resource which appears to have even a weakly significant effect on educational attainment among white women is books per student. The results for the black sample are similar in that no school resource is significantly related to educational attainment, but the coefficients on three of the four school resources are larger. The only

${ }^{5}$ See Table A.1 for the proportion of each variable missing. It is particularly high for father's education for black women. 
TABLE 1

\section{Ordered Probit of Educational Attainment of White Women with Right Censoring}

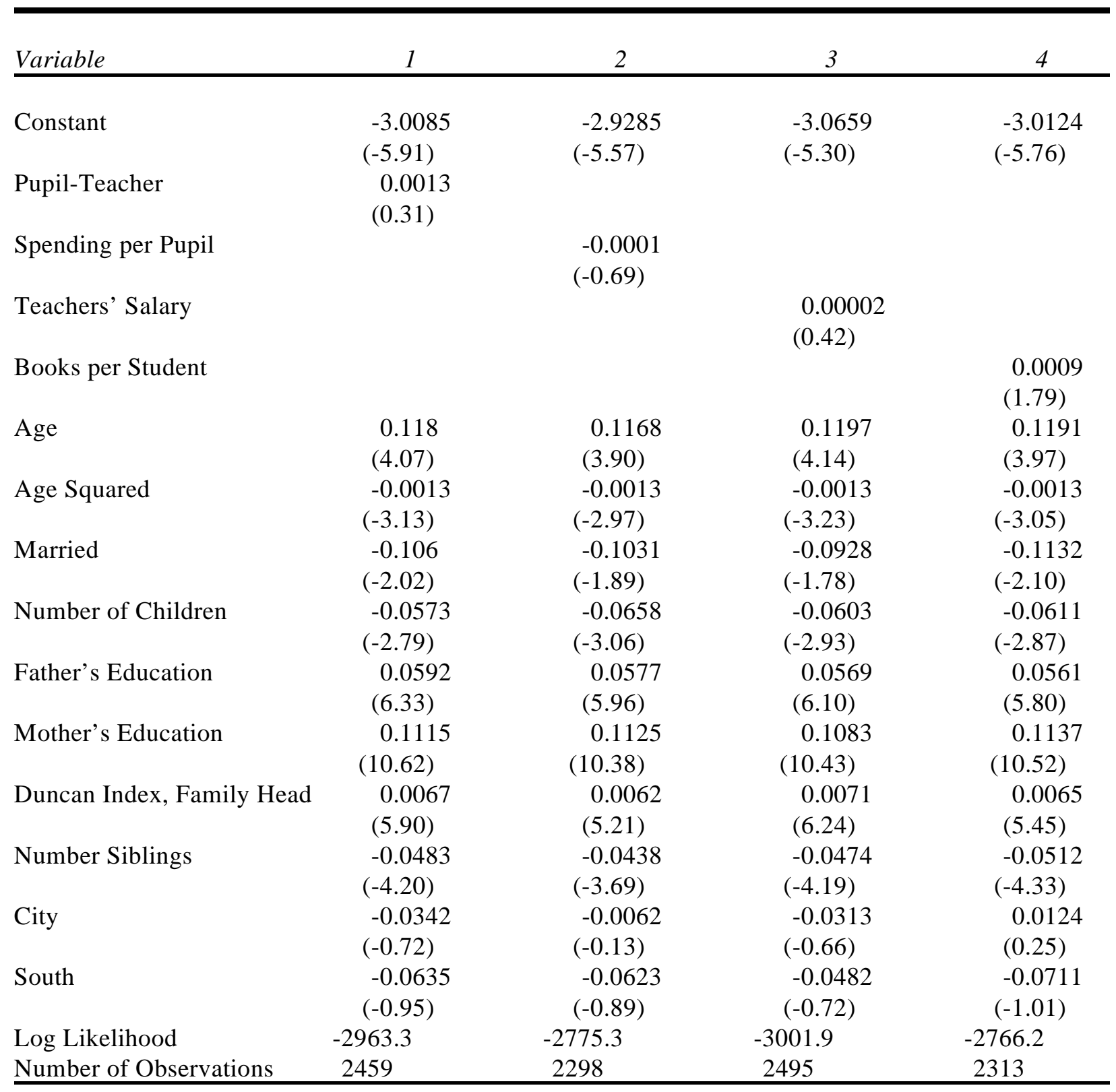

Note: Other regressors not shown are dummies for eight of nine Census regions to indicate the location of the school, and four dummies indicating missing values for the four family background variables (mother's and father's education, Duncan index, and number of siblings). T-statistics are shown in parentheses. 
TABLE 2

Ordered Probit of Educational Attainment of Black Women with Right Censoring

\begin{tabular}{|c|c|c|c|c|}
\hline Variable & 1 & 2 & 3 & 4 \\
\hline Constant & $\begin{array}{l}-4.7510 \\
(-4.52)\end{array}$ & $\begin{array}{l}-4.5007 \\
(-4.01)\end{array}$ & $\begin{array}{l}-5.7828 \\
(-5.07)\end{array}$ & $\begin{array}{l}-4.9311 \\
(-4.70)\end{array}$ \\
\hline Pupil-Teacher & $\begin{array}{l}-0.0149 \\
(-1.22)\end{array}$ & & & \\
\hline Spending per Pupil & & $\begin{array}{l}-0.0005 \\
(-1.42)\end{array}$ & & \\
\hline Teachers' Salary & & & $\begin{array}{l}0.0001 \\
(1.57)\end{array}$ & \\
\hline Books per Student & & & & $\begin{array}{l}0.0016 \\
(1.42)\end{array}$ \\
\hline Age & $\begin{array}{c}0.2521 \\
(4.88)\end{array}$ & $\begin{array}{c}0.2230 \\
(4.09)\end{array}$ & $\begin{array}{c}0.2492 \\
(4.84)\end{array}$ & $\begin{array}{l}0.2537 \\
(4.80)\end{array}$ \\
\hline Age Squared & $\begin{array}{l}-0.0033 \\
(-4.49)\end{array}$ & $\begin{array}{l}-0.0029 \\
(-3.71)\end{array}$ & $\begin{array}{l}-0.0033 \\
(-4.44)\end{array}$ & $\begin{array}{l}-0.0034 \\
(-4.45)\end{array}$ \\
\hline Married & $\begin{array}{c}0.1187 \\
(1.42)\end{array}$ & $\begin{array}{l}0.1424 \\
(1.61)\end{array}$ & $\begin{array}{l}0.1507 \\
(1.79)\end{array}$ & $\begin{array}{l}0.1188 \\
(1.37)\end{array}$ \\
\hline Number of Children & $\begin{array}{l}-0.2083 \\
(-5.83)\end{array}$ & $\begin{array}{l}-0.2276 \\
(-6.05)\end{array}$ & $\begin{array}{l}-0.2233 \\
(-6.20)\end{array}$ & $\begin{array}{l}-0.2236 \\
(-5.90)\end{array}$ \\
\hline Father's Education & $\begin{array}{l}0.0331 \\
(1.98)\end{array}$ & $\begin{array}{l}0.0364 \\
(2.05)\end{array}$ & $\begin{array}{l}0.0300 \\
(1.78)\end{array}$ & $\begin{array}{c}0.0277 \\
(1.61)\end{array}$ \\
\hline Mother's Education & $\begin{array}{l}0.0978 \\
(5.95)\end{array}$ & $\begin{array}{l}0.0862 \\
(4.90)\end{array}$ & $\begin{array}{l}0.0960 \\
(5.84)\end{array}$ & $\begin{array}{l}0.0898 \\
(5.30)\end{array}$ \\
\hline Duncan Index, Family Head & $\begin{array}{l}0.0105 \\
(3.31)\end{array}$ & $\begin{array}{c}0.0097 \\
(2.90)\end{array}$ & $\begin{array}{l}0.0106 \\
(3.31)\end{array}$ & $\begin{array}{l}0.0104 \\
(3.14)\end{array}$ \\
\hline Number Siblings & $\begin{array}{l}-0.0216 \\
(-1.44)\end{array}$ & $\begin{array}{l}-0.0191 \\
(-1.20)\end{array}$ & $\begin{array}{l}-0.0233 \\
(-1.54)\end{array}$ & $\begin{array}{l}-0.0223 \\
(-1.47)\end{array}$ \\
\hline City & $\begin{array}{c}0.0109 \\
(0.11)\end{array}$ & $\begin{array}{l}0.1416 \\
(1.43)\end{array}$ & $\begin{array}{l}-0.0168 \\
(-0.17)\end{array}$ & $\begin{array}{l}0.0443 \\
(0.46)\end{array}$ \\
\hline South & $\begin{array}{l}-0.0468 \\
(-0.48)\end{array}$ & $\begin{array}{l}-0.0640 \\
(-0.61)\end{array}$ & $\begin{array}{l}-0.0621 \\
(-0.63)\end{array}$ & $\begin{array}{l}-0.0355 \\
(-0.36)\end{array}$ \\
\hline Log Likelihood & -926.67 & -830.63 & -920.23 & -873.64 \\
\hline Number of Observations & 777 & 697 & 775 & 734 \\
\hline
\end{tabular}

Note: Other regressors not shown are dummies for eight of nine Census regions to indicate the location of the school, and four dummies indicating missing values for the four family background variables (mother's and father's education, Duncan index, and number of siblings). T-statistics are shown in parentheses. 
exception is spending per pupil, which in both samples has a negative relation to educational attainment.

The picture that emerges from these tables, of little significant link between school resources and education, but with more consistent and stronger effects among black women, is reinforced by Tables 3 and 4. These tables show the results from running tobit models of actual years of schooling, while accounting for right censoring among those still enrolled in school or college at the time of the final observation. There is one school input which is nearly significant at 5 percent for white women: books per student. Again, the pupil-teacher and spending measures have perverse signs among white women, and teachers' salary does not appear to be strongly linked to education for white women.

Among black women, in all cases except for spending per pupil, the coefficients are larger than for white women in the sense that additional school inputs have a larger predicted impact on years of schooling. In the case of teachers' salary, the coefficient is weakly significant ( $\mathrm{p}$-value $=0.09$ ). In the cases of the pupil-teacher ratio and books per student, the level of significance is in the 10 to 15 percent range.

The predicted impacts of additional school inputs on years of education for black women are in some cases meaningful. Most impressively, a 10 percent increase in the starting salary of teachers with a bachelor's degree, or $\$ 605$, is predicted to increase black women's education by about 0.1 year. A 10 percent reduction in class size is predicted to increase black women's educational attainment by 0.07 year. Similar proportional changes in the other two school inputs do not lead to changes in education which are as large. (In the case of spending per pupil, education is predicted to fall.) The corresponding changes predicted for white women are much smaller: only for teachers' salary and books per student is there a positive measured link between education and inputs, and the coefficients are in both cases much smaller than they are for black women. 
TABLE 3

Tobit Model for Educational Attainment of White Women

\begin{tabular}{|c|c|c|c|c|}
\hline Variable & 1 & 2 & 3 & 4 \\
\hline Constant & $\begin{array}{l}5.7171 \\
(6.43)\end{array}$ & $\begin{array}{l}5.8075 \\
(6.34)\end{array}$ & $\begin{array}{l}5.7008 \\
(5.58)\end{array}$ & $\begin{array}{l}5.7470 \\
(6.34)\end{array}$ \\
\hline Pupil-Teacher & $\begin{array}{l}0.0053 \\
(0.68)\end{array}$ & & & \\
\hline Spending per Pupil & & $\begin{array}{l}-0.0003 \\
(-0.97)\end{array}$ & & \\
\hline Teachers' Salary & & & $\begin{array}{l}0.00002 \\
(0.21)\end{array}$ & \\
\hline Books per Student & & & & $\begin{array}{l}0.0017 \\
(1.90)\end{array}$ \\
\hline Age & $\begin{array}{c}0.1727 \\
(3.38)\end{array}$ & $\begin{array}{l}0.1778 \\
(3.38)\end{array}$ & $\begin{array}{l}0.1755 \\
(3.46)\end{array}$ & $\begin{array}{l}0.1762 \\
(3.35)\end{array}$ \\
\hline Age Squared & $\begin{array}{l}-0.0018 \\
(-2.53)\end{array}$ & $\begin{array}{l}-0.0019 \\
(-2.53)\end{array}$ & $\begin{array}{l}-0.0019 \\
(-2.64)\end{array}$ & $\begin{array}{l}-0.0019 \\
(-2.55)\end{array}$ \\
\hline Married & $\begin{array}{l}-0.2250 \\
(-2.33)\end{array}$ & $\begin{array}{l}-0.2413 \\
(-2.40)\end{array}$ & $\begin{array}{l}-0.2205 \\
(-2.29)\end{array}$ & $\begin{array}{l}-0.2428 \\
(-2.46)\end{array}$ \\
\hline Number of Children & $\begin{array}{l}-0.0713 \\
(-1.88)\end{array}$ & $\begin{array}{l}-0.0944 \\
(-2.38)\end{array}$ & $\begin{array}{l}-0.0757 \\
(-1.99)\end{array}$ & $\begin{array}{l}-0.0806 \\
(-2.06)\end{array}$ \\
\hline Father's Education & $\begin{array}{c}0.1109 \\
(6.47)\end{array}$ & $\begin{array}{c}0.1100 \\
(6.18)\end{array}$ & $\begin{array}{l}0.1093 \\
(6.38)\end{array}$ & $\begin{array}{c}0.1043 \\
(5.90)\end{array}$ \\
\hline Mother's Education & $\begin{array}{c}0.2061 \\
(10.86)\end{array}$ & $\begin{array}{c}0.2126 \\
(10.82)\end{array}$ & $\begin{array}{c}0.2039 \\
(10.86)\end{array}$ & $\begin{array}{c}0.2120 \\
(10.89)\end{array}$ \\
\hline Duncan Index, Family Head & $\begin{array}{c}0.0140 \\
(6.65)\end{array}$ & $\begin{array}{c}0.0126 \\
(5.75)\end{array}$ & $\begin{array}{l}0.0145 \\
(6.94)\end{array}$ & $\begin{array}{c}0.0135 \\
(6.21)\end{array}$ \\
\hline Number Siblings & $\begin{array}{l}-0.0823 \\
(-3.92)\end{array}$ & $\begin{array}{l}-0.0743 \\
(-3.41)\end{array}$ & $\begin{array}{l}-0.0796 \\
(-3.85)\end{array}$ & $\begin{array}{l}-0.0865 \\
(-4.02)\end{array}$ \\
\hline City & $\begin{array}{l}-0.0303 \\
(-0.35)\end{array}$ & $\begin{array}{c}0.0181 \\
(0.20)\end{array}$ & $\begin{array}{l}-0.0230 \\
(-0.26)\end{array}$ & $\begin{array}{l}0.0463 \\
(0.50)\end{array}$ \\
\hline South & $\begin{array}{l}-0.0928 \\
(-0.74)\end{array}$ & $\begin{array}{l}-0.0974 \\
(-0.75)\end{array}$ & $\begin{array}{l}-0.0817 \\
(-0.65)\end{array}$ & $\begin{array}{l}-0.1422 \\
(-1.10)\end{array}$ \\
\hline Log Likelihood & -4941.3 & -4616.7 & -5013.7 & -4629.0 \\
\hline Number of Observations & 2459 & 2298 & 2495 & 2313 \\
\hline
\end{tabular}

Note: Other regressors not shown are dummies for eight of nine Census regions to indicate the location of the school, and four dummies indicating missing values for the four family background variables (mother's and father's education, Duncan index, and number of siblings). T-statistics are shown in parentheses. 
TABLE 4

Tobit Model for Educational Attainment of Black Women

\begin{tabular}{|c|c|c|c|c|}
\hline Variable & 1 & 2 & 3 & 4 \\
\hline Constant & $\begin{array}{l}3.9722 \\
(2.31)\end{array}$ & $\begin{array}{l}4.1849 \\
(2.34)\end{array}$ & $\begin{array}{l}1.8959 \\
(1.02)\end{array}$ & $\begin{array}{l}2.9506 \\
(1.72)\end{array}$ \\
\hline Pupil-Teacher & $\begin{array}{l}-0.0334 \\
(-1.58)\end{array}$ & & & \\
\hline Spending per Pupil & & $\begin{array}{l}-0.0004 \\
(-0.70)\end{array}$ & & \\
\hline Teachers' Salary & & & $\begin{array}{l}0.0002 \\
(1.70)\end{array}$ & \\
\hline Books per Student & & & & $\begin{array}{l}0.0031 \\
(1.61)\end{array}$ \\
\hline Age & $\begin{array}{l}0.3936 \\
(4.64)\end{array}$ & $\begin{array}{l}0.3339 \\
(3.76)\end{array}$ & $\begin{array}{c}0.3898 \\
(4.61)\end{array}$ & $\begin{array}{l}0.4238 \\
(4.86)\end{array}$ \\
\hline Age Squared & $\begin{array}{l}-0.0052 \\
(-4.25)\end{array}$ & $\begin{array}{l}-0.0043 \\
(-3.36)\end{array}$ & $\begin{array}{l}-0.0051 \\
(-4.20)\end{array}$ & $\begin{array}{l}-0.0056 \\
(-4.49)\end{array}$ \\
\hline Married & $\begin{array}{l}0.1965 \\
(1.36)\end{array}$ & $\begin{array}{l}0.2415 \\
(1.60)\end{array}$ & $\begin{array}{l}0.2372 \\
(1.63)\end{array}$ & $\begin{array}{l}0.1852 \\
(1.24)\end{array}$ \\
\hline Number of Children & $\begin{array}{l}-0.3493 \\
(-5.88)\end{array}$ & $\begin{array}{l}-0.3597 \\
(-5.87)\end{array}$ & $\begin{array}{l}-0.3701 \\
(-6.21)\end{array}$ & $\begin{array}{l}-0.3681 \\
(-5.88)\end{array}$ \\
\hline Father's Education & $\begin{array}{l}0.0793 \\
(2.73)\end{array}$ & $\begin{array}{l}0.0905 \\
(2.96)\end{array}$ & $\begin{array}{l}0.0783 \\
(2.67)\end{array}$ & $\begin{array}{l}0.0758 \\
(2.53)\end{array}$ \\
\hline Mother's Education & $\begin{array}{l}0.1513 \\
(5.41)\end{array}$ & $\begin{array}{l}0.1309 \\
(4.41)\end{array}$ & $\begin{array}{l}0.1526 \\
(5.45)\end{array}$ & $\begin{array}{l}0.1370 \\
(4.75)\end{array}$ \\
\hline Duncan Index, Family Head & $\begin{array}{c}0.0201 \\
(3.63)\end{array}$ & $\begin{array}{l}0.0188 \\
(3.27)\end{array}$ & $\begin{array}{l}0.0199 \\
(3.55)\end{array}$ & $\begin{array}{l}0.0186 \\
(3.22)\end{array}$ \\
\hline Number Siblings & $\begin{array}{l}-0.0306 \\
(-1.19)\end{array}$ & $\begin{array}{l}-0.0260 \\
(-0.97)\end{array}$ & $\begin{array}{l}-0.0341 \\
(-1.31)\end{array}$ & $\begin{array}{l}-0.0273 \\
(-1.04)\end{array}$ \\
\hline City & $\begin{array}{l}-0.0316 \\
(-0.19)\end{array}$ & $\begin{array}{l}0.1875 \\
(1.11)\end{array}$ & $\begin{array}{l}-0.0891 \\
(-0.53)\end{array}$ & $\begin{array}{l}0.0493 \\
(0.30)\end{array}$ \\
\hline South & $\begin{array}{l}0.0290 \\
(0.17)\end{array}$ & $\begin{array}{l}0.0093 \\
(0.05)\end{array}$ & $\begin{array}{l}0.0243 \\
(0.14)\end{array}$ & $\begin{array}{l}0.0588 \\
(0.34)\end{array}$ \\
\hline Log Likelihood & -1524.9 & -1361.6 & -1518.2 & -1443.0 \\
\hline Number of Observations & 777 & 697 & 775 & 734 \\
\hline
\end{tabular}

Note: Other regressors not shown are dummies for eight of nine Census regions to indicate the location of the school, and four dummies indicating missing values for the four family background variables (mother's and father's education, Duncan index, and number of siblings). T-statistics are shown in parentheses. 
In these models, omitted variable bias is a concern. Although I have added four measures of family background, there may exist omitted family socioeconomic traits which are positively related to educational attainment of women. If these are correlated with school resources, biased estimates of the impact of school resources could result. There are two scenarios to consider. First, if unmeasured family socioeconomic status is positively correlated with school resources (which is likely due to the large extent to which local property taxes finance public schools), then the coefficients on the school resources could be biased upward. On the other hand, as a result of a long series of court decisions, compensatory finance reforms designed to increase school expenditures for minority students could conceivably have created a negative correlation between unmeasured socioeconomic status and school resources. Without full measures for family background, I cannot test for these two possibilities explicitly. But Table A.4 shows the correlations between the four school inputs and the four family background measures which are included in both the educational attainment models and the wage regressions to be discussed later. For both races, there appears to be a weak but positive association between school resources and measures of family socioeconomic status. The correlations tend to be stronger and more consistent among blacks. For instance, among black women an increase in father's years of schooling is associated with smaller classes, higher spending per pupil, higher teacher salaries, and more books per student. Among white women the same patterns hold except for teachers' salaries, although the correlations are typically weaker.

The implications of this table are that if school resources are similarly correlated with unmeasured family socioeconomic status, and if this unmeasured component of socioeconomic status is positively related to educational attainment, then the foregoing models will have overstated the impact of school spending on educational attainment. The upward bias that would result would probably be higher for blacks than for whites, given the relative strengths of the correlations indicated in Table A.4. Of course, the same problem may occur in the wage models described below. 
In summary, the data suggest a strong link between educational attainment and personal background, but at best a statistically weak link between attainment and school resources. An interesting pattern emerges: perhaps due to smaller sample size, the sample of blacks shows a lower level of significance of the personal background variables. But the black sample reveals a more statistically significant impact of spending on teachers' salaries and on reducing class size than does the much larger white sample. But even for black women, the links are only weakly significant. The size of the coefficients on school resources is also larger in the black sample for the class size, teachers' salary, and books per student variables. The only school input which is even marginally significantly linked to white women's educational attainment is books per student.

\subsection{The Determinants of Women's Earnings}

I now examine the impact of school resources on women's earnings. Evidence from the above section strongly suggests that years of schooling is an endogenous function of personal background (and perhaps of school resources). Therefore, in this section, I estimate a reduced form wage equation which does not condition on educational attainment. A second advantage of estimating a reduced form model is that it avoids the difficult issue of deciding whether school resources affect earnings directly (a levels effect) or only by increasing the returns to years of education (an interaction effect), or both. Heckman, Layne-Farrar, and Todd (1995), in the context of the literature which models Census wages on school resources proxied by school resources in the worker's state of birth, show that the estimated impact of term length and teacher salary on wages weakens considerably once one allows for a levels as well as an interaction effect. For class size, addition of a levels effect can either weaken or strengthen the estimated impact on wages, depending on the specification and Census year used. Estimation of a reduced form reduces the risk of misspecification.

The dependent variable in these regressions is the natural log of the hourly wage. Since I am estimating a reduced form, the regressors include the same regressors used to model educational 
attainment in the previous section. In addition, dummies for the year in which the wage is observed are added for all survey years except $1991 .^{6}$

In order to control for selection into employment by women, a Heckman two-step estimator is used. In the first-stage probit model for whether the woman is employed at the time of the given survey, the regressors include the complete set of wage equation regressors, in addition to a variable indicating the woman's number of children under 2 years old. This variable is in addition to the total number of children, which appears in both the wage regression and the probit for employment status. The presence of very young children in the household is likely to (and in fact, does) have a significant negative impact on labor force participation, because it will increase the reservation wage. But it is less likely to affect current wages conditional upon working: if child-raising reduces women's human capital in the formal labor market due to reduced work experience and on-the-job training, then it is the cumulative number of children, rather than the number of young children at the time of the interview, which should have the main effect on the woman's stock of human capital, and hence her wage.

Although the first-stage probits are not shown, the additional variable which is hypothesized to predict employment — the number of children under 2 years of age-performs well, with t-statistics of 17 to -18 for white women and -7 to -8 for black women.

Tables 5 through 8 show the earnings equations for women. All t-statistics are corrected for heteroskedasticity induced by use of the selectivity correction. Each table summarizes results for one school input, with regressions for white and black women presented together to facilitate comparisons. As mentioned in the introduction, a key question in the school quality literature is whether the returns to school spending increase with the worker's age; the NLS-YW is particularly suited to addressing this

${ }^{6}$ Thus the regressions, which use the log of nominal wages as the dependent variable, are equivalent to a model with log wages which are expressed in 1991 prices for all years. 
question since wage observations in the samples range from age 18 up to age 50 for white women and 18 to 49 for black women.

Table 5 models log wages as a function of the same background regressors used in the models of educational attainment, as well as year dummies and the pupil-teacher ratio. The personal background variables enter in a highly significant fashion, in the expected directions. Some notable differences between the wage functions of black and white women emerge, in particular with respect to the sign of the marital status dummy and the relative sizes of some of the coefficients on the background variables, such as the dummy indicating residence in the South. The teacher-pupil ratio is large, negative, and highly significant for black women. In contrast, using the sample of white women, the teacher-pupil ratio is significant but has a positive sign. (Grogger 1996 reports similar findings using both High School and Beyond and the National Longitudinal Study of the High School Class of 1972.) As shown in regression \#2, in the white sample there is no evidence that the impact of changing the pupil-teacher ratio changes with age of the worker. For the black sample, there is some evidence of the effect strengthening with the worker's age, but the interaction term is not significant at 5 percent. The bottom of the table lists the elasticity of the wage with respect to the pupil-teacher ratio. The elasticity is positive and significantly different from zero for white women, and negative and significantly below zero for black women. The latter elasticity is very close to the level of -0.099 which I have calculated as the average in the literature on men's earnings which measures class size at the state level. In contrast, existing school-level analyses of the effect of class size on men's earnings, as summarized in Betts 1996a, on average report an elasticity of earnings with respect to the pupil-teacher ratio of 0.037 . Thus the elasticity for white women found here is very close to the school-level elasticities found for men, while that for black women is very close to the more optimistic results typically found for males in the state-level literature. 
TABLE 5

Models of Log Hourly Wages as a Function of the Pupil-Teacher Ratio

\begin{tabular}{|c|c|c|c|c|}
\hline \multirow[b]{2}{*}{ Variable } & \multicolumn{2}{|c|}{ White Women } & \multicolumn{2}{|c|}{ Black Women } \\
\hline & 1 & 2 & 3 & 4 \\
\hline \multirow[t]{2}{*}{ Constant } & -0.5082 & -0.4941 & 0.6099 & 0.4007 \\
\hline & $(-5.61)$ & $(-4.78)$ & $(3.28)$ & $(2.04)$ \\
\hline \multirow[t]{2}{*}{ (Pupil-Teacher)/1000 } & 2.1658 & 1.4631 & -5.3075 & 5.1819 \\
\hline & $(3.42)$ & $(0.60)$ & $(-3.44)$ & $(0.84)$ \\
\hline \multirow{2}{*}{ Pupil-Teacher*Age/1000 } & & 0.0234 & & -0.3500 \\
\hline & & $(0.26)$ & & $(-1.68)$ \\
\hline \multirow[t]{2}{*}{ Age } & 0.1338 & 0.1333 & 0.0952 & 0.1013 \\
\hline & $(23.75)$ & $(22.52)$ & $(7.74)$ & $(8.51)$ \\
\hline \multirow[t]{2}{*}{ Age Squared } & -0.0017 & -0.0017 & -0.0014 & -0.0014 \\
\hline & $(-18.90)$ & $(-18.90)$ & $(-6.86)$ & $(-6.62)$ \\
\hline \multirow[t]{2}{*}{ Married } & -0.0558 & -0.0559 & 0.0592 & 0.0589 \\
\hline & $(-4.61)$ & $(-4.62)$ & $(5.62)$ & $(5.60)$ \\
\hline \multirow[t]{2}{*}{ Number of Children } & -0.1239 & -0.1240 & -0.0649 & -0.0644 \\
\hline & $(-16.26)$ & $(-16.28)$ & $(-7.92)$ & $(-7.79)$ \\
\hline \multirow[t]{2}{*}{ Father's Education } & 0.0036 & 0.0036 & 0.0142 & 0.0141 \\
\hline & $(2.66)$ & $(2.66)$ & $(6.87)$ & $(6.81)$ \\
\hline \multirow[t]{2}{*}{ Mother's Education } & 0.0149 & 0.0149 & 0.0145 & 0.0145 \\
\hline & $(9.68)$ & $(9.67)$ & $(5.47)$ & $(5.48)$ \\
\hline \multirow[t]{2}{*}{ Duncan Index Family Head } & 0.0012 & 0.0012 & 0.0029 & 0.0028 \\
\hline & $(6.98)$ & $(6.98)$ & $(7.20)$ & $(7.18)$ \\
\hline \multirow[t]{2}{*}{ Number of Siblings } & -0.0073 & -0.0073 & -0.0025 & -0.0025 \\
\hline & $(-4.39)$ & $(-4.39)$ & $(-1.24)$ & $(-1.23)$ \\
\hline \multirow[t]{2}{*}{ City } & 0.0775 & 0.0776 & 0.0569 & 0.0563 \\
\hline & $(11.37)$ & $(11.37)$ & $(4.40)$ & $(4.35)$ \\
\hline \multirow[t]{2}{*}{ South } & -0.0910 & -0.0909 & -0.2590 & -0.2577 \\
\hline & $(-7.30)$ & $(-7.30)$ & $(-16.89)$ & $(-16.84)$ \\
\hline \multirow[t]{2}{*}{ Inverse Mills Ratio } & 0.1917 & 0.1922 & 0.0003 & -0.0023 \\
\hline & $(4.47)$ & $(4.49)$ & $(0.00)$ & $(-0.03)$ \\
\hline Number of Observations & 18415 & 18415 & 6027 & 6027 \\
\hline R Squared & 0.6366 & 0.6366 & 0.6914 & 0.6916 \\
\hline Adjusted R Squared & 0.6358 & 0.6358 & 0.6894 & 0.6895 \\
\hline \multirow{2}{*}{ Elasticity } & 0.0441 & 0.0444 & -0.1158 & -0.1160 \\
\hline & $(3.42)$ & $(3.30)$ & $(-3.44)$ & $(-3.44)$ \\
\hline
\end{tabular}

Note: T-statistics for the coefficients and for the elasticity of wages with respect to the school input appear in parentheses. The t-statistics are based on White standard errors. Other regressors are dummies for eight of nine Census regions indicating location of the school and dummies for all years but 1991. 
Table 6 reports results for models which include spending per pupil in the school district as an explanatory factor. Spending per pupil is not significantly related to the log hourly wage for either sample. For white women the coefficient again has a perverse sign. Note that in the sample of black women, there is highly significant evidence that the impact of spending per pupil on earnings declines with the age of the worker-in other words, the impact of school resources appears to depreciate once workers enter the labor market. Both samples produce estimated elasticities of hourly earnings with respect to spending per pupil which are far below the 0.0961 average I reported (Betts 1996a) as the average found in studies of the impact of district level spending on adult males' earnings.

Table 7 shows the findings when the starting salaries of teachers with bachelor's degrees are used as an explanatory factor. In neither sample is this school input significantly related to earnings, although it becomes significant at 7 percent in regression 3 for black women. Neither sample suggests positive age dependence. As with the other school inputs, the elasticity of wages with respect to teachers' starting salaries is larger for black women than for white women. Recall that the teacher salary variable is based on district-wide averages. The elasticities reported here (0.06 for whites and 0.11 for blacks) fall below the average of 0.22 for existing district-level studies but well above the school-level average of -0.03 , as reported in my review of the literature (1996a).

Table 8 shows that books per student are strongly and positively related to wages for black women, but strongly negatively related to wages for white women. In my earlier work (1995) and work by Kohen (1971) and Parnes and Kohen (1975), no significant link is reported between earnings of men and books per student at their high schools. ${ }^{7}$ Note that in the white sample, the impact of book resources on white women's earnings appears to weaken significantly with the women's age, again suggesting depreciation of any human capital which book resources help to develop.

${ }^{7}$ However, the latter two papers use books per student as part of a "school quality" index, so that it is not possible to state with certainty that books per student have no effect on earnings in their sample. 
TABLE 6

Models of Log Hourly Wages as a Function of Spending per Pupil

\begin{tabular}{|c|c|c|c|c|}
\hline \multirow[b]{2}{*}{ Variable } & \multicolumn{2}{|c|}{ White Women } & \multicolumn{2}{|c|}{ Black Women } \\
\hline & 1 & 2 & 3 & 4 \\
\hline \multirow[t]{2}{*}{ Constant } & -0.4325 & -0.5001 & 0.4528 & 0.1125 \\
\hline & $(-4.58)$ & $(-4.71)$ & $(2.36)$ & $(0.52)$ \\
\hline \multirow[t]{2}{*}{ (Spending per Pupil)/1000 } & -0.0151 & 0.1039 & 0.0457 & 0.6215 \\
\hline & $(-0.66)$ & $(1.21)$ & $(1.06)$ & $(4.13)$ \\
\hline \multirow[t]{2}{*}{ Spending per Pupil*Age/100 } & & -0.0039 & & -0.0190 \\
\hline & & $(-1.35)$ & & $(-3.74)$ \\
\hline \multirow[t]{2}{*}{ Age } & 0.1326 & 0.1346 & 0.0978 & 0.1099 \\
\hline & $(22.56)$ & $(22.18)$ & $(7.24)$ & $(7.86)$ \\
\hline \multirow[t]{2}{*}{ Age Squared } & -0.0017 & -0.0017 & -0.0014 & -0.0014 \\
\hline & $(-17.96)$ & $(-17.89)$ & $(-6.38)$ & $(-6.53)$ \\
\hline \multirow[t]{2}{*}{ Married } & -0.0581 & -0.0582 & 0.0606 & 0.0614 \\
\hline & $(-4.74)$ & $(-4.74)$ & $(5.42)$ & $(5.49)$ \\
\hline \multirow[t]{2}{*}{ Number of Children } & -0.1302 & -0.1304 & -0.0667 & -0.0666 \\
\hline & $(-16.56)$ & $(-16.60)$ & $(-7.22)$ & $(-7.21)$ \\
\hline \multirow[t]{2}{*}{ Father's Education } & 0.0052 & 0.0053 & 0.0138 & 0.0142 \\
\hline & $(3.74)$ & $(3.75)$ & $(6.15)$ & $(6.29)$ \\
\hline \multirow[t]{2}{*}{ Mother's Education } & 0.0140 & 0.0140 & 0.0109 & 0.0109 \\
\hline & $(8.80)$ & $(8.79)$ & $(3.79)$ & $(3.79)$ \\
\hline \multirow[t]{2}{*}{ Duncan Index Family Head } & 0.0011 & 0.0011 & 0.0027 & 0.0027 \\
\hline & $(6.21)$ & $(6.20)$ & $(6.38)$ & $(6.34)$ \\
\hline \multirow[t]{2}{*}{ Number of Siblings } & -0.0064 & -0.0064 & -0.0057 & -0.0058 \\
\hline & $(-3.77)$ & $(-3.79)$ & $(-2.52)$ & $(-2.54)$ \\
\hline \multirow[t]{2}{*}{ City } & 0.0876 & 0.0877 & 0.0755 & 0.0743 \\
\hline & $(12.47)$ & $(12.48)$ & $(5.61)$ & $(5.52)$ \\
\hline \multirow[t]{2}{*}{ South } & -0.0866 & -0.0857 & -0.2541 & -0.2540 \\
\hline & $(-6.57)$ & $(-6.49)$ & $(-15.07)$ & $(-15.05)$ \\
\hline \multirow[t]{2}{*}{ Inverse Mills Ratio } & 0.2116 & 0.2128 & -0.0288 & -0.0296 \\
\hline & $(4.79)$ & $(4.82)$ & $(-0.33)$ & $(-0.34)$ \\
\hline Number of Observations & 17167 & 17167 & 5378 & 5378 \\
\hline R Squared & 0.6365 & 0.6365 & 0.6873 & 0.6881 \\
\hline Adjusted R Squared & 0.6356 & 0.6357 & 0.6850 & 0.6857 \\
\hline \multirow[t]{2}{*}{ Elasticity } & -0.0089 & -0.0085 & 0.0248 & 0.0281 \\
\hline & $(-0.66)$ & $(-0.63)$ & $(1.06)$ & $(1.22)$ \\
\hline
\end{tabular}

Note: T-statistics for the coefficients and for the elasticity of wages with respect to the school input appear in parentheses. The t-statistics are based on White standard errors. Other regressors are dummies for eight of nine Census regions indicating location of the school and dummies for all years but 1991. 
TABLE 7

Models of Log Hourly Wages as a Function of Teachers' Starting Salaries

\begin{tabular}{|c|c|c|c|c|}
\hline \multirow[b]{2}{*}{ Variable } & \multicolumn{2}{|c|}{ White Women } & \multicolumn{2}{|c|}{ Black Women } \\
\hline & 1 & 2 & 3 & 4 \\
\hline \multirow[t]{2}{*}{ Constant } & -0.5441 & -0.4402 & 0.4590 & 0.5384 \\
\hline & $(-5.55)$ & $(-2.33)$ & $(2.51)$ & $(1.84)$ \\
\hline \multirow[t]{2}{*}{ (Teachers' Salary)/1000 } & 0.0106 & -0.0064 & 0.0176 & 0.0048 \\
\hline & $(1.47)$ & $(-0.24)$ & $(1.79)$ & $(0.13)$ \\
\hline \multirow[t]{2}{*}{ Teachers' Salary*Age/1000 } & & 0.0006 & & 0.0004 \\
\hline & & $(0.62)$ & & $(0.33)$ \\
\hline \multirow[t]{2}{*}{ Age } & 0.1353 & 0.1318 & 0.0940 & 0.0912 \\
\hline & $(24.18)$ & $(16.33)$ & $(7.71)$ & $(6.26)$ \\
\hline \multirow[t]{2}{*}{ Age Squared } & -0.0017 & -0.0017 & -0.0014 & -0.0014 \\
\hline & $(-19.31)$ & $(-19.31)$ & $(-6.85)$ & $(-6.83)$ \\
\hline \multirow[t]{2}{*}{ Married } & -0.0501 & -0.0502 & 0.0606 & 0.0605 \\
\hline & $(-4.24)$ & $(-4.24)$ & $(5.78)$ & $(5.77)$ \\
\hline \multirow[t]{2}{*}{ Number of Children } & -0.1255 & -0.1255 & -0.0688 & -0.0686 \\
\hline & $(-16.64)$ & $(-16.65)$ & $(-7.93)$ & $(-7.91)$ \\
\hline \multirow[t]{2}{*}{ Father's Education } & 0.0030 & 0.0030 & 0.0145 & 0.0145 \\
\hline & $(2.19)$ & $(2.19)$ & $(6.91)$ & $(6.91)$ \\
\hline \multirow[t]{2}{*}{ Mother's Education } & 0.0148 & 0.0148 & 0.0136 & 0.0136 \\
\hline & $(9.79)$ & $(9.79)$ & $(5.35)$ & $(5.34)$ \\
\hline \multirow[t]{2}{*}{ Duncan Index Family Head } & 0.0013 & 0.0013 & 0.0027 & 0.0027 \\
\hline & $(7.88)$ & $(7.87)$ & $(6.61)$ & $(6.60)$ \\
\hline \multirow[t]{2}{*}{ Number of Siblings } & -0.0057 & -0.0057 & -0.0051 & -0.0051 \\
\hline & $(-3.55)$ & $(-3.56)$ & $(-2.44)$ & $(-2.43)$ \\
\hline \multirow[t]{2}{*}{ City } & 0.0773 & 0.0773 & 0.0537 & 0.0538 \\
\hline & $(11.34)$ & $(11.34)$ & $(4.06)$ & $(4.07)$ \\
\hline \multirow[t]{2}{*}{ South } & -0.0870 & -0.0869 & -0.2575 & -0.2575 \\
\hline & $(-6.94)$ & $(-6.93)$ & $(-17.16)$ & $(-17.16)$ \\
\hline \multirow[t]{2}{*}{ Inverse Mills Ratio } & 0.1855 & 0.1856 & 0.0114 & 0.0096 \\
\hline & $(4.38)$ & $(4.39)$ & $(0.14)$ & $(0.12)$ \\
\hline Number of Observations & 18727 & 18727 & 6007 & 6007 \\
\hline R Squared & 0.6371 & 0.6371 & 0.6908 & 0.6908 \\
\hline Adjusted R Squared & 0.6363 & 0.6363 & 0.6888 & 0.6888 \\
\hline \multirow[t]{2}{*}{ Elasticity } & 0.0646 & 0.0658 & 0.1054 & 0.1056 \\
\hline & $(1.47)$ & $(1.48)$ & $(1.79)$ & $(1.79)$ \\
\hline
\end{tabular}

Note: T-statistics for the coefficients and for the elasticity of wages with respect to the school input appear in parentheses. The t-statistics are based on White standard errors. Other regressors are dummies for eight of nine Census regions indicating location of the school and dummies for all years but 1991. 
TABLE 8

Models of Log Hourly Wages as a Function of Books per Student

\begin{tabular}{|c|c|c|c|c|}
\hline \multirow[b]{2}{*}{ Variable } & \multicolumn{2}{|c|}{ White Women } & \multicolumn{2}{|c|}{ Black Women } \\
\hline & 1 & 2 & 3 & 4 \\
\hline \multirow{2}{*}{ Constant } & -0.4121 & -0.4738 & 0.8258 & 0.8177 \\
\hline & $(-4.44)$ & $(-4.87)$ & $(4.33)$ & $(4.12)$ \\
\hline \multirow[t]{2}{*}{ (Books per Student)/1000 } & -0.2282 & 0.3574 & 0.3814 & 0.4889 \\
\hline & $(-3.12)$ & $(1.23)$ & $(2.67)$ & $(0.79)$ \\
\hline \multirow{2}{*}{ Books per Student*Age/1000 } & & -0.0193 & & -0.0036 \\
\hline & & $(-1.92)$ & & $(-0.17)$ \\
\hline \multirow[t]{2}{*}{ Age } & 0.1331 & 0.1353 & 0.0790 & 0.0792 \\
\hline & $(22.99)$ & $(22.88)$ & $(6.12)$ & $(6.08)$ \\
\hline \multirow[t]{2}{*}{ Age Squared } & -0.0017 & -0.0017 & -0.0012 & -0.0012 \\
\hline & $(-18.32)$ & $(-18.37)$ & $(-5.53)$ & $(-5.56)$ \\
\hline \multirow[t]{2}{*}{ Married } & -0.0569 & -0.0575 & 0.0606 & 0.0606 \\
\hline & $(-4.53)$ & $(-4.58)$ & $(5.63)$ & $(5.62)$ \\
\hline \multirow[t]{2}{*}{ Number of Children } & -0.1252 & -0.1253 & -0.0566 & -0.0568 \\
\hline & $(-16.23)$ & $(-16.26)$ & $(-6.71)$ & $(-6.75)$ \\
\hline \multirow[t]{2}{*}{ Father's Education } & 0.0027 & 0.0027 & 0.0135 & 0.0135 \\
\hline & $(1.87)$ & $(1.87)$ & $(6.35)$ & $(6.34)$ \\
\hline \multirow[t]{2}{*}{ Mother's Education } & 0.0168 & 0.0168 & 0.0087 & 0.0087 \\
\hline & $(10.57)$ & $(10.61)$ & $(3.21)$ & $(3.24)$ \\
\hline \multirow{2}{*}{ Duncan Index Family Head } & 0.0010 & 0.0010 & 0.0027 & 0.0027 \\
\hline & $(5.89)$ & $(5.87)$ & $(6.55)$ & $(6.57)$ \\
\hline \multirow[t]{2}{*}{ Number of Siblings } & -0.0065 & -0.0065 & -0.0023 & -0.0023 \\
\hline & $(-3.85)$ & $(-3.82)$ & $(-1.11)$ & $(-1.12)$ \\
\hline \multirow[t]{2}{*}{ City } & 0.0806 & 0.0808 & 0.0738 & 0.0739 \\
\hline & $(11.01)$ & $(11.04)$ & $(5.67)$ & $(5.68)$ \\
\hline \multirow[t]{2}{*}{ South } & -0.0903 & -0.0905 & -0.2667 & -0.2668 \\
\hline & $(-6.83)$ & $(-6.84)$ & $(-17.23)$ & $(-17.29)$ \\
\hline \multirow[t]{2}{*}{ Inverse Mills Ratio } & 0.1984 & 0.2000 & -0.0645 & -0.0627 \\
\hline & $(4.51)$ & $(4.55)$ & $(-0.76)$ & $(-0.75)$ \\
\hline Number of Observations & 17326 & 17326 & 5730 & 5730 \\
\hline R Squared & 0.6355 & 0.6356 & 0.6939 & 0.6939 \\
\hline Adjusted R Squared & 0.6347 & 0.6347 & 0.6918 & 0.6918 \\
\hline \multirow[t]{2}{*}{ Elasticity } & -0.0202 & -0.0203 & 0.0285 & 0.0284 \\
\hline & $(-3.12)$ & $(-3.14)$ & $(2.67)$ & $(2.67)$ \\
\hline
\end{tabular}

Note: T-statistics for the coefficients and for the elasticity of wages with respect to the school input appear in parentheses. The t-statistics are based on White standard errors. Other regressors are dummies for eight of nine Census regions indicating location of the school and dummies for all years but 1991. 
In summary, a clear pattern emerges in the log wage regressions. In the case of all four measures of school resources, the elasticity of earnings with respect to spending on the given resource is much higher for black women than for white women. The statistically most significant results for black women are findings of a positive link between their earnings and spending on books per student or spending aimed at reducing the pupil-teacher ratio. The impact of teacher's salaries is positive and moderately significant. For spending per pupil, the coefficient was not significant but was positively signed. The results for white women contrast quite sharply. Three of the inputs-pupil-teacher ratio, spending per pupil, and books per student—have the "wrong" sign, which in two cases were significant. The strongest positive result from the analysis of white women's wages concerns teachers' salaries, where the estimated wage elasticity (and t-statistic) were 0.065 (1.47). The confidence interval for this elasticity easily overlaps the elasticity of 0.1065 obtained for black women.

A secondary but important goal of this section was to test further the hypothesis that past school-level analyses have understated the returns to school spending because their samples have typically been confined to young workers in their early twenties. The NLS-YW is well equipped to test this hypothesis, since the mean age of workers in the wage sample is about 30 , with many observations for workers in their late thirties and forties. The lone case in which this hypothesis appeared to apply was the pupil-teacher ratio for black women, for which there was weak evidence of an effect which strengthened with the women's age (with a p-value of about 0.09 ). There were only two cases of statistically significant age dependence near or above the 5 percent level, and here the dependence was negative (for spending per pupil for black women and books per student for white women), suggesting the depreciation of human capital with age. For the other inputs and samples, the evidence suggests no age dependence. These findings thus support my findings (Betts forthcoming 1996b) where I used both Census data and projected mid-career earnings from the NLSY to test for age dependence, and found little evidence in favor of the age-dependence hypothesis. 
I have performed the above analysis separately for black and white women, given that the coefficients on so many background variables appear to be different between the two races. But it remains important to test formally whether the impact of school resources is significantly different between black and white women. I therefore reran all of the models in Tables 5-8, pooling black and white women, and adding interactions between every regressor (including the constant) and BLACK, a dummy for whether the woman was black. In the models with no age interaction with the school input, the t-statistic on the school input interacted with BLACK provides a test for equal effects between the two races. In the case of the models with interactions between the school input and age, a likelihood ratio test was performed for the hypothesis that the two interactions (between BLACK and the school input and between BLACK, the school input and age) do not belong in the model.

The results of these tests confirm the impressions given by Tables $5-8$. With a p-value of less than 0.01 , the hypothesis of equal effect of school inputs on wages for black and white women is rejected for the pupil-teacher ratio (both models), and for books per student (both models). For teacher's salary, the hypothesis was retained in both models; for spending per pupil, the hypothesis was retained in the model with no age interactions but was rejected $(p$-value $=0.028)$ in the model with age interactions. Thus the apparent interracial differences in the effectiveness of the pupil-teacher ratio and books per student, and to some extent overall spending per pupil, are statistically significant.

Several alternative estimation techniques were used. First, to guard against the possibility that outliers in the school inputs are driving the results, I reestimated the basic models (1 and 3$)$ in Tables 5-8 after eliminating observations which appeared to be outliers in the empirical distribution. The potential outliers were chosen by plotting histograms of the school input for the regression sample, and then removing observations that appeared to be isolated observations on either tail. The lower and upper cutoffs for each of the four school inputs were as follows: for the student-teacher ratio, 10 and 50, for expenditures per pupil, 200 and 1000, for teachers' starting salaries, 4000 and 8000, and for 
books per student, 10 and 300. In practice, about 0.5 percent of the sample was removed from either tail for most school inputs. The exception was spending per pupil, where approximately 1.5 percent of the black and white sample observations came from schools with spending per pupil above the upper cutoff of $\$ 1000$.

Table A.5 shows the results. In the rows titled "OLS" are the ordinary least squares results using the full and trimmed samples, with corrections made for sample selectivity and heteroskedasticity. For white women, the exclusion of potential outliers does not appreciably affect the results. The most important change is that the sign on spending per pupil becomes positive for white women in the trimmed sample, although it remains insignificant. For black women, the trimming of the sample has negligible effects for the coefficients on the pupil-teacher and books per student regressors, but in the case of both spending per pupil and teachers' starting salary, the trimmed sample produces quite different results, with both coefficients and t-statistics more than doubling. In the trimmed sample, spending on all four measures of school resources is positively and significantly related to black women's earnings after leaving school. ${ }^{8}$

Two other estimators are also presented in Table A.5, in which a random effects estimator is used to take account of repeated observations on each school, based on the full sample and the trimmed sample. ${ }^{9}$ The results suggest no major changes in interpretation for the results on white women: the coefficients rise or fall, depending on the input in question, and the t-statistics are slightly lower. For

\footnotetext{
${ }^{8}$ The ordered probit and tobit models of education were also rerun using the same criteria to trim the sample. There were only two major changes. First, for white women, in both models books per student, while still positive, becomes insignificant at even 10 percent. Second, for black women, in both models the coefficient on teachers' starting salary becomes significant at 5 percent, and is larger than in the full sample model. For instance, in the tobit model the coefficient and t-statistic on teachers' salary rise to 0.00038 and 2.55 respectively.

${ }^{9}$ Unlike the OLS estimates in the table, the random effects estimators do not correct for heteroskedasticity. However, rerunning the OLS models without White standard errors produced tstatistics very close to the heteroskedasticity-robust t-statistics.
} 
the regressions using black women, the changes are slightly more dramatic. For both the pupil-teacher ratio and books per student, the coefficients fall by over half, as do the t-statistics. For spending per pupil and teachers' starting salary, the coefficients generally rise, but the t-statistics fall. The only school input which remains highly significant for black women in the random effects formulation is teacher's salary.

Unfortunately, as shown by the p-values listed in Table A.5, Hausman tests for the consistency of the random effect estimators strongly rejects consistency in every model. These models are likely to have inconsistent coefficients and inconsistent t-statistics as well. Thus, although the models suggest that the relation between school inputs and black women's wages is much less significant than indicated by the OLS models, the random effects estimators are not the preferred estimators given that the null of consistency is strongly rejected in every case. Nevertheless, the results suggest that the high levels of significance of the school inputs in the OLS regressions for black women need to be interpreted with caution.

In summary, the alternative specifications in Table A.5 suggest that some of the estimates for black women are less certain in magnitude and significance than stated in Tables 5-8. The random effects estimates for black women suggest that the school inputs are only weakly significant, with the exception of teachers' starting salary, which remains moderately or strongly significant, depending on the sample. However, this information is of limited use given evidence that the random effect estimators are inconsistent. The estimation of models which exclude potential outliers in the school inputs suggest that both the size and level of significance of spending per pupil and teachers' starting salary are understated in the OLS models for black women. In contrast, the robustness tests in Table A.5 suggest no major changes in the interpretation of the results for white women. 


\section{CONCLUSION}

This paper provides the first attempt to test specifically for a relation between high school resources and the educational attainment and earnings of women after they leave school. The most striking finding of the paper is a pattern in which school resources in general have a stronger effect on wages for black women than for white women, both in terms of statistical significance and elasticities. ${ }^{10}$ For white women, in no case did the results suggest a positive link between school resources and earnings at the 5 percent level. In contrast, for black women school resources were positively and moderately or strongly significantly linked to wages in three of four cases. ${ }^{11}$ The higher level of statistical significance and the higher elasticities for black women is especially notable given that the wage sample for blacks was only a third that for whites. Perhaps the most robust finding in the paper is that of a positive and fairly significant link between black women's wages and teachers' starting salaries.

The conclusions are tempered somewhat by the finding of a positive correlation between most school resources and the four measures of family socioeconomic status used in the models. If a similar correlation exists between school resources and any unmeasured components of socioeconomic status, then the estimated impacts of school resources on schooling and wages may be biased upward. Based on the observed correlations, this problem is likely to be more severe in the sample of black women.

The earlier school-level literature has focused mainly on samples of workers in their twenties. It may be that this literature has typically found no or weak effects of school resources because it takes some time after students graduate for the benefits of school spending to manifest themselves. The NLS-

\footnotetext{
${ }^{10}$ For both races, the school inputs were typically insignificantly linked to educational attainment, but in two cases the elasticities for black women were quite high.

${ }^{11}$ Perhaps the most similar result between races was a weakly significant impact of teachers' salaries on earnings, with an elasticity for white women about 60 percent that for black women.
} 
YW provides a good opportunity to test this possibility, because it contains wage observations on workers between the ages of 18 and 50. The evidence suggests that the age dependence hypothesis is wrong. For most regressions the null of no age dependence was strongly retained; the only strongly significant age dependence in the data was negative, suggesting that if anything the impact of school resources depreciates as workers age.

For white women the wage regressions are quite consistent with the existing school-level literature for males, which finds that educational resources generally have low wage elasticities and low levels of significance. The results for black women, in contrast, produce larger and more significant wage elasticities which are closer to the more optimistic results often found in the state-level literature on men's earnings.

Various interpretations of the differing results between black and white women are possible. One explanation is diminishing returns. In the wage samples, for black women on average the pupilteacher ratio was 7 percent higher, spending per pupil was 8 percent lower, teachers' starting salaries were 1.2 percent lower, and the ratio of books per student was 14 percent lower than for white women. If the private returns to school expenditures are sharply diminishing, then these disparities could explain why the observed returns are so much lower for white women. A related issue concerns whether the family's socioeconomic status is a substitute or a complement to school spending. If it is a substitute, then this would help to explain the much lower returns to school spending for white women relative to black women. To give just one example of the gap in socioeconomic status between the families of black and white women in the wage sample, the average years of schooling among the fathers of the white women was 8.9 years; among black women, the average for father's years of schooling was only 4.7.

The results provide some support for the idea that redistribution of schooling resources between black and white women could narrow somewhat the earnings gap between the races. But such a 
conclusion is somewhat speculative: it may not apply as strongly today as in the 1960s, given the convergence between the races in family environment variables such as parental education over the last thirty years. Also, there are grounds to believe that the interracial disparities in school resources evident in the NLS-YW data, based on a 1968 survey of schools, have to a large extent narrowed over time. For instance, Grogger (1996) reports that in the 1980 survey High School and Beyond, class size, term length, and the level of education of teachers were virtually identical for black and white males. 


\section{APPENDIX \\ TABLE A.1}

Sample Means and Standard Deviations for White and Black Subsamples Used in Models of Educational Attainment

\begin{tabular}{|c|c|c|c|c|}
\hline \multirow[b]{2}{*}{ Variable } & \multicolumn{2}{|c|}{ White Women } & \multicolumn{2}{|c|}{ Black Women } \\
\hline & Mean & S.D. & Mean & S.D. \\
\hline Years of Education & 13.209 & 2.248 & 12.622 & 2.103 \\
\hline $\mathrm{ED}=1$ & 0.122 & 0.328 & 0.222 & 0.416 \\
\hline $\mathrm{ED}=2$ & 0.452 & 0.498 & 0.438 & 0.496 \\
\hline $\mathrm{ED}=3$ & 0.211 & 0.408 & 0.195 & 0.396 \\
\hline $\mathrm{ED}=4$ & 0.152 & 0.360 & 0.101 & 0.302 \\
\hline $\mathrm{ED}=5$ & 0.063 & 0.243 & 0.044 & 0.205 \\
\hline Proportion Enrolled & 0.074 & 0.263 & 0.069 & 0.253 \\
\hline Pupil-Teacher & 20.920 & 5.332 & 21.610 & 3.839 \\
\hline Spending per Pupil & 589.741 & 164.129 & 552.812 & 147.850 \\
\hline Teachers' Salary & 6075.830 & 503.473 & 6045.593 & 618.504 \\
\hline Books per Student & 88.465 & 51.505 & 74.454 & 38.307 \\
\hline Age & 39.436 & 7.601 & 37.703 & 7.924 \\
\hline Age Squared & 1612.937 & 527.478 & 1484.220 & 548.396 \\
\hline Married & 0.699 & 0.459 & 0.412 & 0.493 \\
\hline Number of Children & 1.287 & 1.191 & 1.422 & 1.232 \\
\hline Father's Education & 8.933 & 5.084 & 4.724 & 4.749 \\
\hline Mother's Education & 10.210 & 3.881 & 7.584 & 4.416 \\
\hline Duncan Index, Family Head & 34.399 & 25.048 & 15.458 & 14.941 \\
\hline Number Siblings & 2.821 & 2.054 & 4.865 & 2.901 \\
\hline City & 0.400 & 0.490 & 0.532 & 0.499 \\
\hline South & 0.337 & 0.473 & 0.504 & 0.500 \\
\hline School Region 1 & 0.053 & 0.224 & 0.005 & 0.071 \\
\hline School Region 2 & 0.178 & 0.383 & 0.090 & 0.286 \\
\hline School Region 3 & 0.202 & 0.402 & 0.154 & 0.361 \\
\hline School Region 4 & 0.096 & 0.295 & 0.032 & 0.177 \\
\hline School Region 5 & 0.150 & 0.357 & 0.366 & 0.482 \\
\hline School Region 6 & 0.058 & 0.235 & 0.151 & 0.358 \\
\hline School Region 7 & 0.094 & 0.292 & 0.166 & 0.372 \\
\hline School Region 8 & 0.051 & 0.219 & 0.001 & 0.035 \\
\hline School Region 9 & 0.117 & 0.322 & 0.034 & 0.181 \\
\hline Missing Father's Ed & 0.169 & 0.375 & 0.396 & 0.489 \\
\hline Missing Mother's Ed & 0.071 & 0.257 & 0.161 & 0.368 \\
\hline Missing Duncan & 0.065 & 0.247 & 0.144 & 0.351 \\
\hline Missing \# Siblings & 0.004 & 0.063 & 0.011 & 0.105 \\
\hline
\end{tabular}

Note: The statistics are given for observations for which all of the regressors apart from the school resources are available, and at least one of the school input variables is available. (For all of the variables apart from the school inputs, the number of observations is 2551 for white women and 801 for black women. For the school inputs, the sample sizes are identical to those reported in Table 1.) 
TABLE A.2

Sample Means and Standard Deviations for White and Black Subsamples Used in Wage Models

\begin{tabular}{|c|c|c|c|c|}
\hline \multirow[b]{2}{*}{ Variable } & \multicolumn{2}{|c|}{ White Women } & \multicolumn{2}{|c|}{ Black Women } \\
\hline & Mean & S.D. & Mean & S.D. \\
\hline Log Hourly Wage & 1.375 & 0.720 & 1.272 & 0.706 \\
\hline Pupil-Teacher & 20.363 & 5.177 & 21.821 & 3.809 \\
\hline Spending per Pupil & 590.942 & 163.897 & 541.729 & 143.497 \\
\hline Teachers' Salary & 6069.599 & 496.480 & 5995.141 & 623.412 \\
\hline Books per Student & 88.350 & 52.186 & 74.642 & 38.909 \\
\hline Age & 30.538 & 7.364 & 29.978 & 7.072 \\
\hline Age Squared & 986.813 & 471.316 & 948.670 & 446.459 \\
\hline Married & 0.668 & 0.471 & 0.458 & 0.498 \\
\hline Number of Children & 1.071 & 1.150 & 1.426 & 1.355 \\
\hline Father's Education & 8.858 & 5.029 & 4.707 & 4.634 \\
\hline Mother's Education & 10.195 & 3.797 & 7.484 & 4.331 \\
\hline Duncan Index, Family Head & 34.160 & 24.707 & 15.345 & 14.833 \\
\hline Number Siblings & 2.826 & 2.055 & 4.870 & 2.885 \\
\hline City & 0.394 & 0.489 & 0.496 & 0.500 \\
\hline South & 0.331 & 0.471 & 0.554 & 0.497 \\
\hline School Region 1 & 0.054 & 0.226 & 0.008 & 0.091 \\
\hline School Region 2 & 0.169 & 0.375 & 0.083 & 0.275 \\
\hline School Region 3 & 0.201 & 0.401 & 0.132 & 0.338 \\
\hline School Region 4 & 0.104 & 0.306 & 0.031 & 0.173 \\
\hline School Region 5 & 0.156 & 0.363 & 0.390 & 0.488 \\
\hline School Region 6 & 0.061 & 0.240 & 0.150 & 0.357 \\
\hline School Region 7 & 0.100 & 0.300 & 0.719 & 0.384 \\
\hline School Region 8 & 0.043 & 0.203 & 0.001 & 0.038 \\
\hline School Region 9 & 0.111 & 0.314 & 0.026 & 0.158 \\
\hline Year $=1991$ & 0.066 & 0.248 & 0.057 & 0.232 \\
\hline Year $=1988$ & 0.064 & 0.244 & 0.055 & 0.229 \\
\hline Year=1987 & 0.064 & 0.245 & 0.058 & 0.234 \\
\hline Year $=1985$ & 0.063 & 0.243 & 0.059 & 0.235 \\
\hline Year $=1983$ & 0.056 & 0.229 & 0.057 & 0.232 \\
\hline Year=1982 & 0.061 & 0.239 & 0.061 & 0.239 \\
\hline Year $=1980$ & 0.061 & 0.240 & 0.064 & 0.245 \\
\hline Year $=1978$ & 0.059 & 0.236 & 0.062 & 0.242 \\
\hline Year=1977 & 0.066 & 0.249 & 0.072 & 0.259 \\
\hline Year $=1975$ & 0.070 & 0.255 & 0.075 & 0.263 \\
\hline Year $=1973$ & 0.067 & 0.250 & 0.071 & 0.257 \\
\hline Year $=1972$ & 0.069 & 0.253 & 0.067 & 0.250 \\
\hline Year=1971 & 0.067 & 0.250 & 0.072 & 0.258 \\
\hline Year $=1970$ & 0.063 & 0.243 & 0.066 & 0.248 \\
\hline Year $=1969$ & 0.056 & 0.230 & 0.057 & 0.233 \\
\hline Year $=1968$ & 0.049 & 0.216 & 0.046 & 0.209 \\
\hline
\end{tabular}


TABLE A.2, continued

\begin{tabular}{lllll}
\hline & \multicolumn{2}{c}{ White Women } & & \multicolumn{2}{c}{ Black Women } \\
\cline { 2 - 3 } Variable & Mean & S.D. & & Mean \\
\hline Missing Father's Ed & 0.168 & 0.374 & 0.383 & 0.486 \\
Missing Mother's Ed & 0.067 & 0.250 & 0.163 & 0.369 \\
Missing Duncan & 0.061 & 0.240 & 0.145 & 0.352 \\
Missing \# Siblings & 0.003 & 0.055 & 0.011 & 0.104 \\
Number of Children $<2$ & 0.126 & 0.343 & 0.174 & 0.404 \\
\hline
\end{tabular}

Note: The statistics are given for observations for which all of the regressors apart from the school resources are available, and at least one of the school input variables is available. (For all of the variables except the school inputs, the number of observations is 19160 for white women and 6224 for black women. For the school inputs, the sample sizes are identical to those reported in Table 5.) 
TABLE A.3

Correlations between School Inputs for White and Black Subsamples Used in Education Models

\begin{tabular}{lcccc}
\hline & $\begin{array}{c}\text { Pupil-Teacher } \\
\text { Ratio }\end{array}$ & $\begin{array}{c}\text { Spending per } \\
\text { Pupil }\end{array}$ & $\begin{array}{c}\text { Teachers } \\
\text { Salaries }\end{array}$ & $\begin{array}{c}\text { Books per } \\
\text { Student }\end{array}$ \\
\hline Whites & & & & \\
Pupil-Teacher Ratio & 1.000 & & & \\
Spending per Pupil & -0.228 & 1.000 & & \\
Teachers' Salaries & 0.001 & 0.237 & -0.041 & 1.000 \\
Books per Student & -0.274 & 0.071 & & \\
& & & & \\
Blacks & & & & \\
Pupil-Teacher Ratio & 1.000 & 1.000 & 1.000 & \\
Spending per Pupil & -0.311 & 0.224 & 0.040 & \\
Teachers' Salaries & -0.228 & 0.039 & & \\
Books per Student & -0.343 & & & \\
\hline
\end{tabular}


TABLE A.4

Correlations between School Inputs and Family Background for White and Black Subsamples Used in Education Models

\begin{tabular}{|c|c|c|c|c|}
\hline & $\begin{array}{c}\text { Pupil-Teacher } \\
\text { Ratio }\end{array}$ & $\begin{array}{c}\text { Spending per } \\
\text { Pupil } \\
\end{array}$ & $\begin{array}{c}\text { Teachers' } \\
\text { Salaries } \\
\end{array}$ & $\begin{array}{c}\text { Books per } \\
\text { Student }\end{array}$ \\
\hline \multicolumn{5}{|l|}{ Whites } \\
\hline Father's ED & -0.042 & 0.039 & -0.027 & 0.013 \\
\hline Mother's ED & -0.064 & 0.040 & -0.011 & 0.027 \\
\hline Duncan Index & -0.016 & 0.062 & 0.037 & -0.064 \\
\hline \# Siblings & -0.028 & -0.023 & -0.032 & 0.012 \\
\hline \multicolumn{5}{|l|}{ Blacks } \\
\hline Father's ED & -0.096 & 0.009 & 0.174 & 0.024 \\
\hline Mother's ED & -0.089 & 0.037 & 0.139 & -0.012 \\
\hline Duncan Index & -0.079 & 0.048 & 0.103 & 0.058 \\
\hline \# Siblings & 0.117 & 0.009 & -0.121 & -0.046 \\
\hline
\end{tabular}


TABLE A.5

Estimates of Models on Trimmed and Full Samples by OLS and Random Effects

\begin{tabular}{|c|c|c|c|c|c|}
\hline \multirow[b]{2}{*}{ School Input } & \multirow[b]{2}{*}{ Specification } & \multicolumn{2}{|c|}{ White } & \multicolumn{2}{|c|}{ Black } \\
\hline & & Full & Trimmed & Full & Trimmed \\
\hline \multicolumn{6}{|l|}{$\underline{\text { Sample }}$} \\
\hline \multirow[t]{7}{*}{ Pupil-Teacher/100 } & OLS & 2.1658 & 2.5258 & -5.3075 & -5.3084 \\
\hline & & $(3.42)$ & $(3.05)$ & $(-3.44)$ & $(-3.39)$ \\
\hline & Observations & 18415 & 18174 & 6027 & 6014 \\
\hline & Random Effects & 3.404 & 4.4110 & -1.695 & -1.6003 \\
\hline & & $(2.45)$ & $(2.43)$ & $(-0.49)$ & $(-0.46)$ \\
\hline & Observations & 18415 & 18174 & 6027 & 6014 \\
\hline & p-value & 0.0000 & 0.0000 & 0.0000 & 0.0000 \\
\hline \multirow[t]{7}{*}{ Spend per Pupil/1000 } & OLS & -0.0151 & 0.0255 & 0.0457 & 0.1245 \\
\hline & & $(-0.66)$ & $(1.03)$ & $(1.06)$ & $(2.26)$ \\
\hline & Observations & 17167 & 16811 & 5378 & 5262 \\
\hline & Random Effects & -0.0369 & 0.0097 & 0.0019 & 0.1401 \\
\hline & & $(-0.75)$ & $(0.18)$ & $(0.02)$ & $(1.25)$ \\
\hline & Observations & 17167 & 16811 & 5378 & 5262 \\
\hline & $\mathrm{p}$-value & 0.0000 & 0.0000 & 0.0000 & 0.0000 \\
\hline \multirow[t]{7}{*}{ Teachers' Salary/1000 } & OLS & 0.0106 & 0.0089 & 0.0176 & 0.0558 \\
\hline & & $(1.47)$ & $(1.22)$ & $(1.79)$ & $(5.32)$ \\
\hline & Observations & 18727 & 18711 & 6007 & 5946 \\
\hline & Random Effects & 0.0141 & 0.0115 & 0.0346 & 0.0613 \\
\hline & & $(0.90)$ & $(0.72)$ & $(1.63)$ & $(2.68)$ \\
\hline & Observations & 18727 & 18711 & 6007 & 5946 \\
\hline & p-value & 0.0000 & 0.0000 & 0.0000 & 0.0000 \\
\hline \multirow[t]{7}{*}{ Books per Stud't/1000 } & OLS & -0.2282 & -0.3497 & 0.3814 & 0.3872 \\
\hline & & $(-3.12)$ & $(-4.24)$ & $(2.67)$ & $(2.70)$ \\
\hline & Observations & 17326 & 17134 & 5730 & 5711 \\
\hline & Random Effects & -0.3647 & -0.5512 & 0.1350 & 0.1399 \\
\hline & & $(-2.31)$ & $(-3.13)$ & $(0.44)$ & $(0.45)$ \\
\hline & Observations & 17326 & 17134 & 5730 & 5711 \\
\hline & p-value & 0.0000 & 0.0000 & 0.0000 & 0.0000 \\
\hline
\end{tabular}

Notes: The models correspond to the set of regressors in 1 and 3 in Tables 5-8, including the inverse Mills ratio. See the text for the criteria used for dropping observations in the trimmed samples. The OLS results are corrected for heteroskedasticity; the random effect models are not. The OLS t-statistics change little when the heteroskedasticity correction is not made. The p-values refer to Hausman tests for consistency of the random effects estimates. 


\section{References}

Altonji, Joseph G. 1988. "The Effects of Family Background and School Characteristics on Education and Labor Market Outcomes.” Manuscript, Department of Economics, Northwestern University.

Altonji, Joseph G. and Thomas A. Dunn. 1995. "The Effects of School and Family Characteristics on the Return to Education." National Bureau of Economic Research Working Paper no. 5072.

Betts, Julian R. 1995. "Does School Quality Matter? Evidence from the National Longitudinal Survey of Youth." Review of Economics and Statistics 77: 231-50.

___ 1996a. "Is There a Link between School Inputs and Earnings? Fresh Scrutiny of an Old Literature.” In Does Money Matter? The Effect of School Resources on Student Achievement and Adult Success, ed. Gary Burtless. Washington, D.C.: Brookings Institution.

—__ Forthcoming. 1996b. "Do School Resources Matter Only for Older Workers?" Review of Economics and Statistics 78 (November): 141-191.

Card, David, and Alan B. Krueger. 1996. "Labor Market Effects of School Quality: Theory and Evidence.” National Bureau of Economic Research Working Paper \#5450.

Grogger, Jeff. 1996. "Does School Quality Explain the Recent Black/White Wage Trend?" Journal of Labor Economics 14: 231-53.

Hanushek, Eric A. 1986. "The Economics of Schooling: Production and Efficiency in Public Schools." Journal of Economic Literature 24: 1141-77.

—__ 1989. "The Impact of Differential Expenditures on School Performance." Educational Researcher 18: 45-51, 62.

_—_ 1991. "When School Finance 'Reform' May Not Be Good Policy.” Harvard Journal on Legislation 28: 423-56.

Heckman, James J., Anne S. Layne-Farrar, and Petra E. Todd. 1995. "Does Measured School Quality Really Matter? An Examination of the Earnings-Quality Relationship." National Bureau of Economics Working Paper \#5274.

Kohen, Andrew Ivor. 1971. "Determinants of Early Labor Market Success among Young Men: Ability, Quantity, and Quality of Schooling-A Preliminary Report.” Research Report, Columbus, OH: Center for Human Resource Research, The Ohio State University.

Parnes, Herbert S., and Andrew I. Kohen. 1975. "Occupational Information and Labor Market Status: The Case of Young Men." Journal of Human Resources 10: 44-55.

Taubman, Paul. 1989. "Role of Parental Income in Educational Attainment." American Economic Review 79: 57-61. 
U.S. Bureau of the Census. 1992. Statistical Abstract of the United States 112th ed. Washington, D.C.: U.S. Government Printing Office.

Wachtel, Paul. 1975. "The Effect of School Quality on Achievement, Attainment Levels, and Lifetime Earnings.” Explorations in Economic Research 2: 502-36. 